Original Research Article

\title{
Comparative study of adverse drug reaction pattern of two anti-asthma groups of drugs in a tertiary care hospital
}

\author{
Narendra Babu S. ${ }^{1}$, Vinoth Kumar C. ${ }^{2 *}$, Nandini R. ${ }^{3}$
}

${ }^{1}$ Department of Pharmacology, Govt Vellore-632001 Medical College, Vellore, Tamil Nadu, India

${ }^{2}$ Department of Pharmacology, Govt Sivagangai Medical College, Sivagangai, Tamil Nadu, India

${ }^{3}$ Department of Pharmacology, Institute of Pharmacology, Madras Medical College, Chennai, Tamil Nadu, India

Received: 08 March 2019 Accepted: 15 March 2019

*Correspondence to: Dr. Vinoth Kumar C., Email: vinothcdr@gmail.com

Copyright: (C) the author(s), publisher and licensee Medip Academy. This is an openaccess article distributed under the terms of the Creative Commons Attribution NonCommercial License, which permits unrestricted noncommercial use, distribution, and reproduction in any medium, provided the original work is properly cited.

\begin{abstract}
Background: Bronchial Asthma is one of the worldwide health problems associated with increased morbidity and also mortality. Bronchial Asthma is a disease of airways that is characterized by increased responsiveness of the trachea-bronchial tree. Anti asthmatic drugs are associated with adverse effects which can affect the compliance and course of treatment. Monitoring adverse drug reactions in asthma will play a vital role in alerting physicians about the possibility and circumstances of such events, thereby protecting the user population from avoidable harm.
\end{abstract}

Methods: The study was conducted in 500 bronchial asthma patients (250 patients in Beta 2 agonist group (Salbutamol) and 250 patients in Methylxanthine group (Deriphyllin) who fulfilled the study criteria and were observed for three months at Madras Medical College and Rajiv Gandhi Government General Hospital, Chennai. Their prescriptions were collected and analysed. Adverse drug reactions(ADRs) in each group were collected and evaluated. The causality assessment was done by WHO-UMC assessment scale and severity by using Modified Hartwig-Seigel severity assessment scale.

Results: Total $38 \%$ of patients taking anti-asthma drugs were encountered adverse drug reactions and were more common in elderly females (61 to 70 years). Adverse Drug Reactions were more common in Methylxanthine group (48\%) compared to Beta 2 agonist group (28\%). Headache (38\%) was the commonest ADR in Methylxanthine group and Tremors (31\%) in Beta 2 agonist group. Most of ADRs were mild (95\%), manageable and comes under possible (60\%) category of WHO causality assessment scale.

Conclusions: Treatment of Bronchial Asthma is mainly based on Beta 2 agonist and Methylxanthine group. So, occurrence of ADR is much common. Our study offers a representative idea of the ADR profile of anti asthmatic drugs. Constant vigil in detecting ADRs and subsequent dose adjustments can make therapy with anti asthmatic drugs safer and more effective. This, in turn, will improve compliance.

Keywords: Adverse drug reaction,Bronchial asthma, Beta 2 agonist, Methylxanthine

\section{INTRODUCTION}

Bronchial Asthma is a disease of airways that is characterized by increased responsiveness of the tracheobronchial tree to a multiplicity of stimuli. It is manifested pathophysiologically by a wide spread narrowing of the passages, which may be relieved as a result of therapy and clinically by paroxysms of dyspnoea, cough and wheezing. ${ }^{1}$

Asthma is one of the most common chronic diseases in the world. It is estimated that around 300 million people in the world currently have asthma. ${ }^{2}$ There may be an additional 100 million persons with asthma by $2025 .^{3}$ It is estimated 
that asthma accounts for about 1 in every 250 deaths worldwide. Many of the deaths are preventable, being due to suboptimal long-term medical care and delay in obtaining help during the final attack. ${ }^{4}$

According to National Family Health Survey 2 (NFHS-2) report, the estimated prevalence of asthma in India is 2468 per 100,000 persons. Due to increasing population, predicted increase in the prevalence of asthma will result in a marked increase in the number of asthmatics. ${ }^{5}$

Anti-asthmatic drugs prescribed are Beta 2 agonists, methylxanthines, corticosteroids leukotriene modulators, mast cell stabilisers and monoclonal IgE antibody according to the severity of Asthma. ${ }^{6}$ The drugs are aimed at relieve the acute attacks and maintain remission in the long term.

Adverse Drug Reaction (ADR) is defined by WHO, "As a response which is noxious and unintended and which occurs at doses normally used in humans for the prophylaxis, diagnosis or therapy of disease, or for the modification of physiological function". ${ }^{7}$ As innovation in medicine continues and new drugs are being developed, there is potential for the occurrence of increasing number of ADRs. ${ }^{8}$

As widely used drugs act by interfering with one or more aspects of molecular and cellular function, all of them have the risk of producing some reaction which may not be desirable all the times. ${ }^{9}$

Total $10-15 \%$ of all patients receiving medications are affected by ADR. The incidence of serious ADRs is $6.7 \% .{ }^{10}$ Expenses related to management of ADR accounts for 5 to $9 \%$ of hospital costs. ADRs had been recognised as a major public health issue since they contribute to a sizeable percentage of hospital admissions and also to economic burden to the society.

Anti asthmatic drugs are associated with adverse effects which can affect the compliance and course of treatment. Monitoring Adverse Drug Reactions in asthma will play a vital role in alerting physicians about the possibility and circumstances of such events, thereby protecting the user population from avoidable harm. ${ }^{11}$

In India, adverse drug monitoring activities are still in nascent stage and very few reports available on the ADR profile of medicines in general and anti asthmatic drugs in particular. Hence this study was undertaken to compare the ADR of two anti-asthmatic drug groups.

\section{METHODS}

Our objective of the study was to compare the pattern of Adverse Drug Reactions of two groups of anti-asthmatic drugs (first group-Beta 2 agonists- Salbutamol and second group-Methylxanthines- Deriphyllin)
Ours was a prospective observational study conducted from August 2013 to October 2013 in 500 patients attending Asthma OPD in Rajiv Gandhi Govt General Hospital, Madras Medical College, Chennai, Tamilnadu. This study was started after getting Institutional Ethical committee approval. Written informed consent in local vernacular language was obtained from every patient included in the study at the time of enrolment. Patients diagnosed with Bronchial Asthma were enrolled in the study. The Patients were followed up every week for a period of three months. Demographic details, medication details and relevant lab investigation data were collected.

Prescription of the study patients collected and analysed. The medication details collected from the patients includes name of the drug or drug combination, dosage form, daily dosage, frequency, drugs prescribed by generic or brand name and all the co-prescribed drugs. Casual relationship of the adverse drug effects was done by establishing the temporal association of drug use with Adverse Drug Reaction. Causality assessment was done by using WHO UMC causality assessment scale and Severity assessment was done by using Modified Hartwig and Siegel scale.

\section{Inclusion criteria}

- Age between 18-70 years.

- Gender: both male and female

- Bronchial Asthma Patients with acute exacerbation

- Patients willing to give informed consent.

\section{Exclusion criteria}

- $\quad$ Age below 18 and above 70 .

- Pregnant and lactating females.

- Patients with acute severe asthma.

- Patients with any other systemic illness

- Participation in another clinical study in the last three months

- Patients on other drugs

- Patients not willing to give informed consent

\section{Statistical analysis}

Data were entered in excel spreadsheet and descriptive statistics was used to analyse the data.

\section{RESULTS}

In Rajiv Gandhi Government General Hospital, two anti asthmatic group drugs are issued to the patients in Asthma OPD. They are Beta 2 agonist group (oral Salbutamol $4 \mathrm{mg}$ tablets) and Methylxanthines group (oral Deriphyllin 150 mg tablets).

Total 794 prescriptions were screened. 500 prescriptions which fulfilled the inclusion criteria were analysed. 250 patients in each group were selected. The results of our study are as follows. 
Most of the Bronchial Asthma patients were in the age group of 61-70 years (37\%) followed by 51-60 years $(28 \%)$. Incidence was more in older age (Table 1). $34 \%$ patients were Males. Females constituted $66 \%$, Female to Male ratio was 1.9:1 (Table 2).

Age and sex distribution correlate with the epidemiology of Bronchial Asthma. Out of 500 patients, 250 patients $(50 \%)$ were prescribed Beta 2 agonist group and remaining 250 patients $(50 \%)$ were prescribed Methylxanthine group (Table 3).

Table 1: Age distribution of the patients.

\begin{tabular}{|lll|}
\hline Age group & Number of patients & Percentage \\
\hline $19-30$ yrs & 25 & $5 \%$ \\
\hline $31-40$ yrs & 60 & $12 \%$ \\
\hline $41-50$ yrs & 90 & $18 \%$ \\
\hline $51-60$ yrs & 140 & $28 \%$ \\
\hline $61-70$ yrs & 185 & $37 \%$ \\
\hline Total & 500 & $100 \%$ \\
\hline
\end{tabular}

Table 2: Represents the sex distribution of the patients.

\begin{tabular}{|lll|}
\hline Sex & Number of patients & Percentage \\
\hline Male & 170 & $34 \%$ \\
\hline Female & 330 & $66 \%$ \\
\hline Total & 500 & $100 \%$ \\
\hline
\end{tabular}

Table 3: : Prescribing pattern of anti-asthmatic drugs.

\begin{tabular}{|lll|}
\hline $\begin{array}{l}\text { Anti-asthmatics } \\
\text { drugs }\end{array}$ & Number of patients & Percentage \\
\hline Beta 2 agonist & 250 & $50 \%$ \\
\hline Methylxanthines & 250 & $50 \%$ \\
\hline
\end{tabular}

Table 4: Percentage of patients with ADRs.

\begin{tabular}{|lll|}
\hline ADR & $\begin{array}{l}\text { Number of } \\
\text { patients }\end{array}$ & Percentage \\
\hline Patients with ADRs & 190 & $38 \%$ \\
\hline $\begin{array}{l}\text { Patients without } \\
\text { ADRs }\end{array}$ & 310 & $62 \%$ \\
\hline Total & 500 & $100 \%$ \\
\hline
\end{tabular}

Total 190 patients (38\%) of patients encountered Adverse Drug Reactions (ADRs) (Table 4). Out of 250 patients in the Beta 2 agonist group, 69 patients (28\%) developed ADR. Tremors (38\%) was the commonest ADR in the beta 2 agonist group, followed by nervousness (26\%), headache (13\%), palpitation (13\%), sleeplessness (6\%), dizziness $(4 \%)$ (Table 5). Out of 250 patients in methylxanthine group, 121 patients $(48 \%)$ developed ADR. Headache $(31 \%)$ was the most common ADR in the Methylxanthine group followed by nausea (30\%), vomiting (17\%), insomnia (12\%), palpitation (11\%) (Table 6).
Total $60 \%$ of ADRs were categorised as possible, $32 \%$ were probable and $8 \%$ of them belong to Certain category as per WHO UMC causality assessment scale (Table 7).

Adverse Drug Reactions were categorised as 95\% Mild and 5\% Moderate in severity as per Modified Hartwig and Siegel scale. Most of ADRs were mild, manageable as per WHO protocol (Table 8).

Table 5: Adverse drug reaction pattern of Beta 2 agonist (salbutamol) group.

\begin{tabular}{|l|l|l|}
\hline $\begin{array}{l}\text { Adverse drug } \\
\text { reactions }\end{array}$ & $\begin{array}{l}\text { No. of } \\
\text { patients }\end{array}$ & Percentage \\
\hline Tremors & 26 & $38 \%$ \\
\hline Nervousness & 18 & $26 \%$ \\
\hline Headache & 9 & $13 \%$ \\
\hline Sleeplessness & 4 & $6 \%$ \\
\hline Palpitations & 9 & $13 \%$ \\
\hline Dizziness & 3 & $4 \%$ \\
\hline Total & 69 & $100 \%$ \\
\hline
\end{tabular}

Table 6: Pattern of adverse drug reactions of methylxanthines (deriphyllin) group.

\begin{tabular}{|ll|l|}
\hline $\begin{array}{l}\text { Adverse drug } \\
\text { reactions }\end{array}$ & $\begin{array}{l}\text { No. of } \\
\text { patients }\end{array}$ & Percentage \\
\hline Nausea & 36 & $30 \%$ \\
\hline Vomiting & 21 & $17 \%$ \\
\hline Headache & 37 & $31 \%$ \\
\hline Palpitation & 13 & $11 \%$ \\
\hline Insomnia & 14 & $12 \%$ \\
\hline Total & 121 & $100 \%$ \\
\hline
\end{tabular}

Table 7: Causality assessment of adverse drug reactions using WHO UMC causality assessment scale.

\begin{tabular}{|lll|}
\hline Assessment category & No. of patients & Percentage \\
\hline Certain & 15 & $8 \%$ \\
\hline Probable & 61 & $32 \%$ \\
\hline Possible & 114 & $60 \%$ \\
\hline Total & 190 & $100 \%$ \\
\hline
\end{tabular}

Table 8: Severity assessment of adverse drug reactions by modified Hartwig Siegel severity assessment scale.

\begin{tabular}{|lll|}
\hline Assessment category & No. of patients & Percentage \\
\hline Mild & 181 & $95 \%$ \\
\hline Moderate & 9 & $5 \%$ \\
\hline Severe & 0 & 0 \\
\hline Total & 190 & $100 \%$ \\
\hline
\end{tabular}

\section{DISCUSSION}

Bronchial Asthma is one of the worldwide health problems associated with increased morbidity and also mortality. As a result of their high prevalence, onset at an earlier age and 
chronic persistence, they contribute substantially to the burden of illness worldwide.

In present study, 500 Bronchial Asthma patients with acute exacerbation were evaluated for adverse drug reactions. They were divided into two groups, Beta 2 agonist group (250 patients) and Methylxanthine (250 patients). In Beta 2 agonist group patients were prescribed Tab Salbutamol 4 mg twice daily and in Methylxanthine group patients received Tab. Deriphyllin $150 \mathrm{mg}$ twice daily.

Most of the patients were in the age group of 61-70 years. Males constituted 34\% and females 66\%. Among 500 patients who were on anti-asthmatic drugs, 190 patients developed at least one adverse drug reaction (38\%).

Adverse drug reactions were more in Methylxanthine group (48\%) compared to Beta 2 agonist group (28\%).

Headache $(31 \%)$ was the most common Adverse drug reactions in the Methylxanthine group and tremors (38\%) in the Beta 2 agonists group. About $60 \%$ of ADR comes under possible category of WHO UMC causality assessment scale. Most of the ADRs were mild (95\%) as per Modified Hartwig and Siegel scale.

The adverse drug reaction pattern reported in current study correlates with the results of studies conducted by Kallergis et al, Balaji et al, Vangvcciavong et al. ${ }^{12-15}$

\section{CONCLUSION}

Beta 2 agonist group patients had lesser Adverse Drug Reactions (ADRs) and better compliance than Methylxanthine group. Use of inhalational route of drugs (Beta 2 agonists) can further significantly reduce the adverse drug reactions of the oral route.

Present study offers a representative idea of the ADR comparison profile of anti asthmatic drugs. Constant vigil in detecting ADRs and subsequent dose adjustments can make therapy with anti asthmatic drugs safer and more effective. This, in turn, will improve compliance.

Funding: No funding sources Conflict of interest: None declared

Ethical approval: The study was approved by the Institutional Ethics Committee

\section{REFERENCES}

1. Kasper DL, Braunwald E, Fauci AS, Hauser SL, Longo DL, Loscalzo $\mathrm{J}$ and Jameson JL, eds. Harrison's Principles of Internal Medicine: $18^{\text {th }} \mathrm{Ed}$. McGraw-Hill, New York; 2012:254.

2. Masoli M, Fabian D, Holt S, Beasley R. Global burden of asthma. Developed for the Global Initiative for Asthma (GINA). Allergy. 2004;59:469-78.
3. World health reports 2001. Fifty facts from the world health report 1998: Global Health Situation and Trends: WHO: 2001;1955-2025.

4. Murray CJ, Lopez AD. Global mortality, disability, and the contribution of risk factors: Global Burden of Disease Study. Lancet. 1997 May 17;349(9063):143642.

5. National commission on Macroeconomics and healthBurden of disease in India. Available at: https://www.who.int/macrohealth/action/Report\%20o f\%20the $\% 20$ National $\% 20$ Commission.pdf?ua $=1$. 2005; 251:63.

6. Stock S, Redaelli M, Luengen M, Wendlad G, Civello D, Lauterbach KW: Asthma: prevalence and cost of illness. Eur Resp J. 2005;25:47-53.

7. Geneva: World Health organization. WHO. Requirements for adverse drug reaction reporting: 1975;1039-109. Available at: https://www.who.int/medicines/areas/quality_safety/s afety_efficacy/advdrugreactions/en/.

8. Gross F. Drug utilization-Theory and practice the present situation in the Federal Republic of Germany. Eur J Clin Pharmacol. 1981 Nov 1;19(6):387-94.

9. Stolley PD, Lasagna L. Prescribing patterns of physicians. J Chronic Dis. 1969 Dec;22(6):395-405.

10. Lazarou J, Pomeranz BH, Corey PN. Incidence of adverse drug reactions in hospitalized patients: a metaanalysis of prospective studies. JAMA. 1998 Apr 15;279(15):1200-5.

11. Udomratn $\mathrm{P}, \mathrm{Ng} \mathrm{CH}$, Lin KM, Singh BS, Chui E. Outpatient prescribing practices in Asian Countries. Ethno-psychopharmacology: Advances in current practice. Cambridge: Cambridge University Press. 2008;135-43.

12. Kallergis EM, Manios EG, Kanoupakis EM, Schiza SE, Mavrakis HE, Klapsinos NK, et al. Acute electrophysiologic effects of inhaled salbutamol in humans. Chest. 2005 Jun 1;127(6):2057-63.

13. Bajaj A, Balakrishna S, Sawarkar S. Assessment of therapeutic performances of inhalation aerosols and clinical pharmacist's services in PFT lab. Indian J Hosp Pham. 1999;36:138-42.

14. Vangvcciavong ML. A comparative study of efficacy of salbutamol via metered dose inhaler with volumetric spacer and via dry powder inhaler, easyhaler, to nebulization in mild to moderate severity acute asthma exacerbation in childhood. J Med Assoc Thai. 2008; 91(Suppl 3):S115-S123.

15. Selective beta2 agonists - side effects British National Formulary: $57^{\text {th }}$ Ed., London: BMJ Publishing group Ltd and Royal Pharmaceutical Society Publishing. 2009;148:168.

Cite this article as: Babu NS, Kumar VC, Nandini R. Comparative study of adverse drug reaction pattern of two anti-asthma groups of drugs in a tertiary care hospital. Int J Basic Clin Pharmacol 2019;8:788-91. 